\title{
O DISCURSO DE BARACK OBAMA NO RIO: FUTEBOL, DEMOCRACIA E DEMAGOGIA, EM CLIMA DE "AQUARELA DO BRASIL"
}

\author{
MADEIRA, Ana Maria Gini ${ }^{1}$ \\ MARTINS, Ana Lúcia M. R. Poltronieri
}

\section{1-CONTEXTO SÓCIO-HISTÓRICO}

Conforme observou a mídia brasileira, a primeira visita oficial do presidente Barack Obama ao Brasil coincidiu com outro evento marcante na política brasileira: a eleição de uma mulher para ocupar o cargo de presidente do Brasil, país hoje considerado pelos analistas políticos como a segunda maior democracia do mundo depois dos Estados Unidos da América. Em razão disso, a imprensa brasileira viu nesse gesto um apoio ao projeto político de Dilma Rousseff, ligada ao PT (Partido dos Trabalhadores) e discípula do ex-presidente Luís Inácio Lula da Silva, eleito duas vezes por vias democráticas (eleição direta e universal).

No que diz respeito à figura do presidente norte-americano, Barack Obama tem uma singularidade: é o primeiro presidente negro dos Estados Unidos. No Brasil e em outros países, o fato de o povo norte-americano ter elegido um senador negro democrata para o cargo máximo de uma nação que, há meio século, passou por inúmeros conflitos raciais, simbolizou uma mudança de paradigma para o país que, desde o final da Segunda Guerra Mundial em 1945, dita a ordem sociopolítico-econômica no mundo ocidental.

\footnotetext{
${ }^{1}$ Mestre em Linguística (UFMG), membro do NAD-UFMG (Núcleo de Análise do Discurso), professora aposentada da SME-BH.

${ }^{2}$ Doutoranda em Letras (UERJ) e membro do grupo Semiótica, Leitura e produção de textos (SELEPROT-UERJ). É bolsista da FAPERJ e, durante o período de setembro a dezembro de 2011, foi bolsista CAPES na UBI (Universidade da Beira Interior- Portugal).
} 
Além de estratégias e acordos entre os governantes, Barack Obama marcou em sua agenda de visita ao Brasil um discurso dirigido especialmente ao povo brasileiro. Intitulado informalmente pela imprensa de "Discurso da Cinelândia", lugar no centro do Rio de Janeiro primeiramente escolhido para o discurso em palanque aberto ao povo. O discurso acabou acontecendo no Theatro Municipal do Rio de Janeiro, também na Cinelândia, para um seleto grupo de convidados, representativo, de acordo com a segurança do presidente americano, de vários setores da sociedade brasileira (políticos, empresários, artistas, profissionais liberais, funcionários públicos do primeiro escalão etc). É possível, porém, constatar que o público-alvo que discursivamente se manifesta é aquele esperado para espaço anteriormente previsto.

Nesse sentido, a escolha do "Discurso da Cinelândia" como corpus deste artigo deve-se ao fato de que ele tem como enunciatário o povo brasileiro. De acordo com Charaudeau (2008, p. 187) "em todo o ato de discurso, o propósito é aquilo de que se fala, o projeto que se tem em mente ao tomar a palavra; o que é, afinal, proposto", que, para ele, reflete a visão do enunciador em relação à realidade que o rodeia, pois:

Por mais que se fale (ou escreva) com a finalidade essencial de estabelecer uma relação entre si e o outro e de influenciá-lo, tentando persuadi-lo ou seduzi-lo, essa relação seria vazia de sentido se não tivesse por objeto certa visão que trazemos do mundo, isto é, o conhecimento que se tem da realidade e os julgamentos que dela se fazem. O homem é tomado tanto por um desejo de inteligibilidade do mundo quanto de troca com o outro. (CHARAUDEAU, 2008, p. 187)

\section{2-OS IMAGINÁRIOS SOCIODISCURSIVOS}

O "Discurso da Cinelândia" ${ }^{3}$ é considerado um discurso político, porque "toca à organização da vida em sociedade e ao governo da coisa pública" (CHARAUDEAU, 2008, p. 189). O macrotema

\footnotetext{
${ }^{3}$ Seguimos a diagramação do tradutor brasileiro para o portal G1. Assim, o texto constitui-se de 34 parágrafos, separados por um espaço de linha.
} 
(CHARAUDEAU, 2008, p. 188), ou campo temático, proposto pelo enunciador, apresenta-se nos dois últimos períodos que compõem o sexto $\left(6^{\circ}\right)$ parágrafo, que revela também a quem se dirige 0 discurso:

\begin{abstract}
Ontem tive um encontro com sua maravilhosa nova presidente, Dilma Rousseff, e conversamos sobre como fortalecer a parceria entre nossos governos. Mas hoje quero falar diretamente com o povo brasileiro sobre como podemos fortalecer a amizade entre nossos países. Vim aqui para compartilhar algumas ideias, pois quero falar sobre os valores que compartilhamos, as esperanças que temos em comum e a diferença que podemos fazer juntos.
\end{abstract}

Repare que, no sexto $\left(6^{\circ}\right)$ parágrafo, a palavra à qual as associações se dirigem é "amizade". Evidentemente que a escolha e o emprego desse léxico ultrapassam o uso comum, pois em se tratando de um discurso político, a "amizade" entre dois países implica um jogo de interesses em diferentes campos da vida pública, tais como a política, a economia, as relações internacionais etc. Desse modo, tem- se a "amizade" como "parceria entre nossos governos"/ "compartilhar algumas ideias"/ "valores que compartilhamos"/ "as esperanças que temos em comum"/ "a diferença que podemos fazer juntos".

Sempre seguindo Charaudeau (2008), pode-se dividir o "Discurso da Cinelândia" em três partes. Essas partes, de acordo com Charaudeau (2008, p. 210-245), compõem os três grandes tipos de "imaginários sociodiscursivos": o "imaginário da tradição", o "imaginário da modernidade" e "o imaginário da soberania popular". Mas o que são os "imaginários sociodiscursivos"? Conforme Charaudeau (2008, p. 203), os "imaginários sociodiscursivos" advêm de inúmeras disciplinas (Antropologia Social, Filosofia, Sociologia etc) que irão compor um quadro interdisciplinar, visto que nenhuma 
disciplina isolada explica os valores demarcados pelos "imaginários sociodiscursivos", pois:

À medida que esses saberes, enquanto representações sociais, constroem o real como universo de significação, segundo o princípio de coerência, falaremos de "imaginários". E tendo em vista que estes são identificados por enunciados linguageiros produzidos de diferentes formas, mas semanticamente reagrupáveis, nós os chamaremos de "imaginários discursivos". Enfim, considerando que circulam no interior de um grupo social, instituindo- se em normas de referência por seus membros, falaremos de "imaginários sociodiscursivos. (CHARAUDEAU, 2008, p. 203)

É notório que o discurso proferido pelo presidente Barack Obama foi escrito para o povo brasileiro, mesmo que, no primeiro (10) parágrafo, ele evoque o Rio de Janeiro e a sua antonomásia mundialmente conhecida, "Cidade Maravilhosa". Neste mesmo parágrafo, encontra-se, em forma de cumprimento, a primeira referência direta ao povo brasileiro- "Boa tarde, todo o povo brasileiro", no qual o uso do quantificador "todo" reforça a ênfase sobre o termo lexical "povo". Outra característica marcante no discurso é a escolha de termos lexicais de fácil compreensão para todos os presentes. Quase não há no discurso termos advindos de terminologias de áreas restritas ao campo político, apesar de o "Discurso da Cinelândia" ser um discurso político, visto que o seu enunciador não se despiu do seu "ethos" político. Charaudeau (2008, p. 207) enfatiza que a escolha dos termos faz parte da estratégia de materialização do imaginário sociodiscursivo e, consequentemente, de persuasão, pois "esses textos, ditados, slogans, enunciados diversos, são apresentados de maneira simples, pois devem ser compreendidos pela maioria, e desempenham diversos papéis de apelo, de manifesto, de acusação, de polêmica, de reivindicação" (ibidem, p. 207). 
Nesse sentido, encontram-se, nos quatro parágrafos seguintes, os imaginários sociodiscursivos advindos de espaços da intertextualidade e da interdiscursividade. Charaudeau chama a atenção para o fato de que os "imaginários sociodiscursivos" "dão testemunho das identidades coletivas, da percepção que os indivíduos e os grupos têm dos acontecimentos, dos julgamentos que fazem de suas atividades sociais" (CHARAUDEAU, ibidem, p.207). No segundo $\left(^{\circ}\right)$ parágrafo, os trechos "o calor e a generosidade do espírito brasileiro" e "Eu sei que os brasileiros não abrem mão de seu futebol tão facilmente" são percursos temáticos recorrentes no imaginário do estrangeiro em relação ao Brasil. A figura do Brasil como "terra de gente simpática e hospitaleira" e "país do futebol" já faz parte de um estereótipo coletivo estável, reconhecido por brasileiros e estrangeiros. O recurso à interdiscursividade continua nos quatro parágrafos seguintes em um percurso temático que liga o Brasil à ideia de paraíso abaixo da linha do Equador, pois, em suas palavras, "tinha música e dança", "vi essa beleza nas encostas dos morros, nas infindáveis milhas de areia e oceano e nas vibrantes e diversificadas multidões de brasileiros que vieram aqui hoje". No quarto (40) parágrafo, há de se ressaltar uma intertextualidade explícita, ou seja, com a citação da fonte, com a música "País Tropical", de Jorge Ben Jor, no trecho "um país tropical abençoado por Deus e bonito por natureza".

\section{1- O IMAGINÁRIO SOCIODISCURSIVO DA "TRADIÇÃO"}

De acordo com Charaudeau (2008, p. 211), a "tradição" constitui-se como um imaginário que "é sustentado por discursos que se referem a um mundo longínquo no tempo, no qual os indivíduos teriam conhecido um estado de pureza". É um discurso de "retorno às fontes", ou seja, de retorno à origem ou às raízes de um povo ou nação. Assim, comumente, encontra-se, nos discursos dos políticos, a 
história dos seus ascendentes, de sua terra ou de sua origem linguística. Charaudeau (2008, p. 213) enumera quatro aspectos ligados ao discurso da "tradição": a natureza, a pureza, a fidelidade e a responsabilidade.

A "natureza", que, de acordo com Charaudeau (2008), relembra aos homens que eles são como as espécies animais e, assim, devem ficar atentos à defesa de seu território, isto é, de sua terra. A "pureza" se insere no discurso político por meio das marcas que reafirmam a identidade de uma comunidade ou de um país. Talvez o caso mais conhecido da presença da "pureza" no discurso político seja o arianismo de Hitler. A "fidelidade" é, como bem diz Charaudeau (ibidem, p. 213), um "valor moral, um dever de assumir a origem" como uma herança que deve ser seguida à risca, sem que haja mudanças desses valores. Daí advém a "responsabilidade", pois, ao se assumir a "fidelidade", a comunidade se torna uma espécie de depositário das vozes daqueles que a precederam. Caberá a cada geração guardar essa riqueza e transmiti-la às gerações vindouras. Todos esses quatro aspectos permeiam o "Discurso da Cinelândia" e estão presentes nos parágrafos que seguem:

Se você parar para pensar, as jornadas dos EUA e do Brasil começaram de formas parecidas. São duas terras com abundantes recursos naturais, terras natais de povos indígenas antiquíssimos. As Américas foram descobertas por homens que vieram do outro lado do oceano como um "novo mundo" e colonizadas pelos pioneiros que ampliaram os territórios rumo ao Oeste atravessando imensas fronteiras. Nos tornamos colônias dominadas por coroas distantes, mas logo declaramos nossa independência e em seguida recebemos grandes quantidades de imigrantes em nossas costas e mais tarde, depois de muita luta, limpamos a mancha da escravidão de nossas terras.

Os EUA foram a $1^{a}$ nação a reconhecer a independência do Brasil e a $1^{a}$ a estabelecer um 
posto diplomático neste país. O primeiro líder de um país a visitar os EUA foi Dom Pedro II. Na Segunda Guerra Mundial nossos corajosos homens e mulheres lutaram lado a lado pela liberdade. E depois da guerra, nossas duas nações lutaram para conseguir as bênçãos plenas da liberdade.

Nas ruas dos EUA, homens e mulheres marcharam e sangraram e alguns até morreram para que todos os cidadãos pudessem usufruir das mesmas liberdades e oportunidades, não importa como fosse sua aparência, não importa de onde você viesse. No Brasil vocês lutaram contra duas décadas de ditadura, lutando pelo mesmo direito de serem ouvidos, o direito de serem livres, livres do medo, livres da necessidade. E mesmo assim, durante anos, a democracia e o desenvolvimento demoraram a se estabelecer e milhões sofreram por causa disso.

Nesses três parágrafos, o sétimo $\left(7^{\circ}\right)$, o oitavo $\left(8^{\circ}\right)$ e o nono $\left(9^{\circ}\right)$, apresenta-se o imaginário da "tradição" dos dois países, Brasil e Estados Unidos, naquilo que de comum os une em virtude da "natureza" e da "pureza": exaltação à terra de origem e às suas riquezas, a colonização e a ideia de um "novo mundo", o sacrifício dos primeiros colonizadores, a abolição da escravatura, a independência e a coragem dos homens e mulheres em luta pela liberdade. A nosso ver, esse discurso da "tradição" no "Discurso da Cinelândia" vem em uma forma de gradação ascendente para a palavra que irá perpassar todo o discurso- a democracia. Todo o discurso da "tradição" justifica, de uma forma ou de outra, as razões pelas quais norte-americanos e brasileiros são fiéis- a "fidelidade"- e responsáveis- a "responsabilidade", pela liberdade e, consequentemente, pela democracia. 


\section{2- O IMAGINÁRIO SOCIODISCURSIVO DA MODERNIDADE}

No subtópico anterior, vimos que o "Discurso da Cinelândia" contém trechos que vão ao encontro daquilo que Charaudeau (2008) designa como "imaginário da Tradição". Agora, veremos que o discurso do presidente Barack Obama remete também ao "imaginário da Modernidade", que, segundo Charaudeau (ibidem, p. 214- 215), ultrapassa o conceito de modernidade como uma época que contraria dogmas e costumes de uma época precedente, como nos movimentos artísticos e literários. Assim, o "imaginário da Modernidade" se caracteriza por:

Um conjunto de representações que os grupos sociais constroem a propósito da maneira como percebem ou julgam seu instante presente, em comparação com o passado, atribuindo-lhe um valor positivo, mesmo quando o criticam. Pode-se, portanto, aventar a hipótese de que, a cada momento presente de sua história, os grupos sociais se dotariam de um imaginário de modernidade, sempre tomando como base a época precedente e procurando legitimá-la: a cada vez está em jogo a legitimidade de uma maneira de ser e de viver, uma visão nova do mundo. (CHARAUDEAU, 2008, p. 215)

No "Discurso da Cinelândia", o passado, um dos traços aos quais se opõe a modernidade, porque o tempo presente sempre será melhor, isto é, "o tempo presente se beneficiaria de um estado de saber superior, primeira caução dessa modernidade" (CHARAUDEAU, ibidem, p. 216), encontra-se na ideia de um "Brasil, país do futuro", difundida pelo governo militar na década de 70, época do "milagre econômico", que fracassou com a crise mundial do petróleo. Nesse sentido, a modernidade se mostra pelo hoje, o tempo presente, como se vê no seguinte parágrafo do discurso de Barack Obama:

Por isso pretendo voltar em 2016 para ver o que acontece. O Brasil foi durante muito tempo um 
país cheio de potencial, mas atrasado pela política, tanto aqui quanto no exterior. Durante muito tempo o Brasil foi o "país do futuro" e disseram para que ele esperasse pelos dias melhores que viriam em breve. Meus amigos, este dia finalmente chegou. Este não é mais o "país do futuro", as pessoas do Brasil devem saber que o futuro já chegou e está aqui agora. É hora de tomar posse dele.

Outro traço marcante no "imaginário da modernidade" é a desconstrução do sonho utópico, considerado um elemento de desmobilização, pois impede a ação, ou melhor, a "eficácia da ação" humana (CHARAUDEAU, 2008, p. 216). Essa "eficácia da ação" humana surge por meio de uma competência e de uma vontade de agir, as quais, juntas, sustentam a base da modernidade no discurso político. Essas características estão presentes no discurso da Cinelândia, pois, somente por meio da competência e da vontade, os povos, nesse caso, o norte- americano e brasileiro, podem, segundo Barack Obama, vencer as adversidades e alcançar o sucesso, que é o que se mostra nos dois parágrafos, o décimo-quinto $\left(15^{\circ}\right)$ e o décimo-sexto $\left(16^{\circ}\right)$ :

Nossos países nem sempre concordaram em tudo. E assim como ocorre com muitas nações, teremos nossas diferenças de opinião ao avançar. Mas estou aqui para lhes dizer que o povo americano não apenas reconhece o sucesso do Brasil, nós torcemos pelo sucesso do Brasil enquanto vocês confrontam os muitos desafios que ainda enfrentam em casa e no exterior, vamos ficar juntos, não são como parceiros sênior e júnior, mas como parceiros iguais, unidos pelo espírito do interesse comum e do respeito mútuo, comprometidos para com o progresso que sei que podermos fazer juntos.

Tenho certeza de que podemos fazer isso. Juntos, podemos aumentar nossa prosperidade em comum. Sendo duas das maiores economias do mundo, trabalhamos lado a lado durante a crise 
financeira para restaurar o crescimento e confiança. E para manter nossas economias crescendo, sabemos do que é necessário em ambas as nações. Precisamos de uma força de trabalho capacitada e é por isso que empresas brasileiras e americanas assumiram um compromisso de aumentar o intercâmbio de estudantes entre nossas nações.

Outras características presentes no "imaginário da modernidade" são a tecnologia e a economia. Esta, segundo Charaudeau (2008, p.218), apresenta-se "como o modo de uma sociedade representar para si a legitimidade de gerir a vida coletiva do ponto de vista da produção e da repartição de riquezas"; aquela, a tecnologia, liga-se às "noções de eficácia, competência e vontade de agir" (ibidem, p.222). Na maioria das vezes, a tecnologia desenvolvese no âmbito de um poder econômico, que, por sua vez, gerencia também a eficácia e a técnica. Não se pode esquecer que, no discurso político, a economia e a tecnologia trabalham juntas a fim de que todos os cidadãos possam usufruir do progresso social, tal como se vê nos parágrafos décimo-sétimo $\left(17^{\circ}\right)$, décimo-oitavo $\left(18^{\circ}\right)$ e décimo-nono $\left(19^{\circ}\right)$ do "Discurso da Cinelândia":

Precisamos de um compromisso com a inovação e a tecnologia, por isso concordamos em aumentar a cooperação entre nossos cientistas, pesquisadores e engenheiros. Precisamos de infra estrutura da mais alta qualidade e por isso as empresas americanas também querem ajudá-los a construir e preparar a cidade para o sucesso olímpico. Numa economia globalizada, os EUA e o Brasil deveriam expandir o comércio, expandir investimentos, de modo a criar novos empregos e novas oportunidades em ambas nossas nações por isso estamos trabalhando para derrubar barreiras para fazer negócios.

Por isso estamos criando relacionamentos mais próximos entre nossos trabalhadores e nossos empreendedores. Juntos também podemos 
trabalhar pela segurança da energia e proteger nosso lindo planeta.

Sendo dois países comprometidos com economias mais verdes, sabemos que a solução definitiva ao desafio da energia virá da criação de fontes de energias limpas e renováveis. Por isso a metade dos carros daqui pode circular com biocombustível e a maior parte de sua eletricidade vem de hidroelétricas. $E$ por isso também demos início a uma nova indústria limpa de energia nos EUA. Por isso os EUA e o Brasil estão criando novas parcerias na área de energia, para compartilhar, criar novos empregos e deixar para nossos filhos um mundo mais limpo e mais seguro do que encontramos.

Charaudeau (ibidem, p.226) destaca o fato de que os discursos da tecnologia e da economia, principalmente o primeiro, "tendem a celebrar os efeitos positivos e a mascarar os negativos", para que haja uma legitimação de suas forças perante a sociedade.

\section{3- O IMAGINÁRIO SOCIODISCURSIVO DA "SOBERANIA POPULAR"}

Em linhas gerais, o conceito de "soberania popular" refere-se a um poder que provém da vontade do povo, uma "entidade abstrata de razão, representante de uma opinião coletiva consensual resultante de uma deliberação ao longo da qual foram confrontados pontos de vista diferentes e tomadas decisões contrárias" (CHARAUDEAU, 2008, p. 227). Isso não quer dizer que o povo será o guia de si mesmo. Desse modo, elegem-se os políticos, que, no sistema democrático, irão ser os mediadores sociais da vontade do povo. É interessante notar que, no discurso político, o termo "nação" é substitutivo de "povo" e vice-versa. Essa troca não acontece deliberadamente, pois, num sentido lato, "nação" refere-se a um conjunto de pessoas que se reúnem, tendo em vista interesses, 
origem e objetivos comuns, que é o que se estabelece no vigésimo $\left(20^{\circ}\right)$ parágrafo do "Discurso da Cinelândia":

Juntas, nossas duas nações também podem ajudar a defender a segurança de nossos cidadãos. Estamos trabalhando juntos para deter 0 narcotráfico que destruiu vidas demais neste hemisfério. Buscamos o objetivo de um mundo sem armas nucleares. Estamos trabalhando juntos para aumentar nossa segurança ente hemisférios. Da África ao Haiti, estamos trabalhando lado a lado para combater a fome, doença e corrupção que podem apodrecer uma sociedade e roubar seres humanos de sua dignidade e oportunidades.

Conforme Charaudeau (2008, p. 228), o imaginário da "soberania popular" engloba três tipos de discursos: o discurso do direito à identidade, o do igualitarismo e o da solidariedade.

Para Charaudeau (ibidem) a pergunta essencial do discurso do direito à identidade é "de qual grupo se trata?". Nesse sentido, reivindica-se a diferença entre grupos e não a integração, apesar de ser a integração uma via "universalista" e também uma forma de "soberania popular". Barack Obama não segue nem uma via nem outra, pois, é claro, no seu "Discurso da Cinelândia", a escolha por uma terceira via, denominada por Charaudeau (2008, p. 230) de "valor de tolerância (o melting-pot americano)", na qual "grupos diferentes coexistem pacificamente em nome de princípios coletivos" (ibidem). Encontra-se, assim, no discurso político que segue essa via, a palavra "diversidade", que engloba um aspecto positivo que se liga ao multiculturalismo. É o que mostra o vigésimo-quarto (240) parágrafo:

Vocês são a prova de que justiça social e inclusão social podem ser melhor conquistadas por meio da liberdade e que a democracia é a maior parceira do progresso humano. Também acreditamos que em países tão grandes e diversos quanto os nossos, moldados por gerações de imigrantes de todas as raças, fés e culturas, a democracia dá a maior 
esperança de que todos os cidadãos sejam tratados com dignidade e respeito. E que podemos resolver nossas diferenças pacificamente $e$ encontrar força em nossa diversidade.

O "discurso da soberania popular" também inclui o discurso do igualitarismo. Para Charaudeau (2008), o igualitarismo abrange a igualdade em diferentes instâncias: a do poder econômico, a da identidade cidadã e a da lei.

O discurso do igualitarismo ligado ao poder econômico prega que todos devem ter acesso à formação e, consequentemente, ao trabalho, para que possam satisfazer as suas necessidades materiais (bens de consumo) e, por fim, assegurem a dignidade humana. A igualdade do ponto de vista da identidade cidadã é o princípio da não discriminação por motivos diversos (raça, etnia, religião, idade, sexo, política etc), que é o assunto tratado no vigésimo- sexto (260) parágrafo:

Mas também sabemos que existem certas aspirações compartilhadas por todo ser humano. Todos queremos ser livres, queremos ser ouvidos, todos ansiamos por viver sem medo ou discriminação. Todos queremos escolher como seremos governados. Todos querem moldar seu próprio destino. Esses não são ideais americanos ou ideais brasileiros, não são ideais ocidentais, são direitos universais. E devemos apoiá-los em toda parte. Hoje estamos vendo a luta por esses direitos acontecendo no Oriente Médio e no Norte da África.

Entretanto, Charaudeau (2008) ressalta que a igualdade cidadã pode desencadear uma neutralização do indíviduo em relação ao cidadão, na medida em que indivíduo perde a consciência de sua unicidade diante da igualdade.

O discurso do igualitarismo mais conhecido é o da lei, visto que é a própria lei quem diz "Todos são iguais perante a lei", ou seja, a justiça não deve ver a quem ela impõe a lei. Cabe frisar que o 
discurso do igualitarismo ligado à lei também pode promover discursos de sanção, ou melhor, de repressão, como é o caso do discurso da segurança, que reivindica que "todo cidadão tem direito a uma proteção que preserve seus bens e sua vida" (CHARAUDEAU, 2008, p. 236)

Por último, há o discurso da solidariedade. Conforme Charaudeau (2008), o discurso da solidariedade está intrinsecamente ligado ao discurso da igualdade. A solidariedade parte do princípio de que todos têm direito à igualdade e, para isso, justificam-se atos e engajamentos de diferentes causas por toda a parte. Em nome da solidariedade, as nações engajam-se em guerras de libertação, fazem acordos econômicos, promovem ações sociais etc. Em contrapartida, Charaudeau (2008) evidencia que o discurso da solidariedade pode também produzir movimentos de insubmissão que afrontam 0 discurso da maioria, o povo, mas, por razões diversas, também acreditam que produz o discurso da soberania popular, como bem se nota nas guerras civis. É interessante notar que os discursos da igualdade e da solidariedade fecham o discurso de Barack Obama no Brasil em diferentes perspectivas: a defesa do movimento "Primavera Árabe", o ensejo de que a democracia seja um bem de todos os povos, e que a prosperidade, os direitos humanos e a liberdade estejam presentes em todas as nações. Os três parágrafos que seguem são representativos das ideias contidas nesses discursos:

Vimos uma revolução nascer de um anseio por dignidade humana básica na Tunísia e vimos manifestantes pacíficos, homens e mulheres, jovens e velhos, cristão e muçulmanos, ocupando praça Tahir e vimos o povo da Líbia se defendendo corajosamente contra um regime determinado a tratar com brutalidade seus próprios cidadãos. Em toda parte vimos jovens se erguendo. Uma nova geração exigindo o direito de determinar seu próprio futuro. 
Desde o início deixamos claro que a mudança que buscam devem ser impulsionadas pelo seu próprio povo. Mas para nossos dois países, para os EUA e para o Brasil - duas nações que passaram muitas gerações lutando para aperfeiçoar suas próprias democracias - os EUA e o Brasil sabem que o futuro de nosso mundo era determinado pelo seu povo. Ninguém pode dizer ao certo como essa mudança terminará. Mas eu sei que mudança não é algo que devemos temer.

Quando os jovens insistem que as correntes da História estão se movendo, a carga do passado pode ser apagada. Quando homens e mulheres exigem pacificamente seus direitos humanos nossa humanidade em comum é acentuada. Onde quer que a luz da liberdade seja acesa, o mundo se torna um mais luminoso.

O "Discurso da Cinelândia", proferido pelo presidente Barack Obama, não foge à regra de um discurso político tradicional, tendo em vista o enunciatário que compõe a sua plateia. A utilização de diferentes "imaginários sociodiscursivos" reflete o saber de crença do enunciador num determinado aqui (lugar) e agora (tempo), visto que, para Charaudeau (2008, p.205), "todo imaginário é um imaginário de verdade que essencializa a percepção do mundo em um saber (provisoriamente) absoluto".

\section{3- A IMAGEM MOSTRADA - O ETHOS}

Discurso (peça de oratória), orador, público ou, neste caso, plateia. O que concluir de uma visita oficial do atual presidente dos Estados Unidos ao Brasil? Seria uma visita de cortesia, para cumprimentar a primeira presidente do Brasil? Terá vindo ele tratar de negócios, assinar acordos, propor parcerias? Ou, já com vistas às próximas eleições nos Estados Unidos, viaja a países dos quais se diz amigo? Seja qual tenha sido a intenção da visita, explicitada por meio de entrevistas e matérias jornalísticas, a nós importa aqui a sua 
palavra, revelada no discurso proferido no Theatro Municipal do Rio de Janeiro, por meio da qual buscaremos identificar o ethos, ou imagem de si que se revela discursivamente.

Ao iniciar a nossa busca pelo estabelecimento do ethos deixado perceber pelo presidente americano, recorremos ao que nos diz Ruth Amossy no texto da introdução de Imagens de si no discurso: a construção do ethos:

Todo ato de tomar a palavra implica a construção de uma imagem de si. Para tanto, não é necessário que o locutor faça seu auto- retrato, detalhe suas qualidades nem mesmo que fale explicitamente de si. Seu estilo, suas competências linguísticas e enciclopédicas, suas crenças implícitas são suficientes para construir uma representação de sua pessoa. (AMOSSY, 2005, p.9)

Ao assumir o lugar do orador, aquele que manifesta suas ideias e crenças por meio da palavra, Barack Obama se deixa perceber e às suas intenções. Por retomarem conceitos propostos por Aristóteles, os estudos atuais sobre a arte de persuadir consideram que orador lança mão três categorias de meios discursivos para influenciar o seu auditório: o logos, relativo ao domínio da razão e que visa convencer por meio das estratégias discursivas escolhidas, o pathos e o ethos, relativos ao domínio da emoção e que seriam responsáveis por persuadir o auditório e assim favorecer ou garantir o sucesso do orador.

Ainda que o discurso de Barack Obama se constitua numa rica peça de análise com relação aos três aspectos citados anteriormente, optamos por nos ocupar apenas do ethos, ou a imagem de si, revelada pelo presidente americano ao se dirigir ao povo brasileiro.

Há duas posições distintas, assumidas pelos atuais estudiosos da argumentação, que retomam aquelas já presentes na Antiguidade. Para alguns estudiosos, a construção do ethos é anterior ao discurso e depende da identidade social do orador. É o dito ethos pré- 
discursivo. Já os que se filiam a Aristóteles consideram ser o ethos um elemento que se constrói no nível do discurso, assim considerado ethos discursivo, dependente do exercício da palavra.

Para Charaudeau (2008, p.115), é preciso considerar esses dois aspectos: o ethos, enquanto imagem que o auditório tem do orador e imagem que o orador pensa que o auditório tem em relação a ele, orador. Considera ainda o teórico francês que a imagem prévia é construída com base em dados preexistentes. Em nosso caso específico, o público, o povo brasileiro, desde a campanha de Barack Obama para a presidência, foi colhendo informações sobre ele por meio da imprensa, das reações dos seus eleitores, dos demais países em relação à sua eleição. Isso fez com que, ao chegar ao Brasil, ele já tivesse sua imagem social e política consolidada. Assim pensando, consideramos necessário tratar aqui, ainda que sem muitos detalhes, desse aspecto, ou seja, o ethos prévio ou pré-discursivo.

Quem é Barack Obama? Primeiro presidente negro dos Estados Unidos, de origem humilde, ele se revela como uma pessoa que preserva os valores de família, apesar da sua vida familiar conturbada, um representante dos anseios de uma classe média em crise, uma pessoa simples, apesar do seu status político, excelente orador, que geralmente não se furta a tratar dos temas os mais diversos, e comprometido em melhorar a qualidade de vida do povo americano. De maneira geral, uma imagem positiva, o que fez com que ele fosse aqui recebido como uma pessoa muito próxima ao povo brasileiro.

Assim também, não veio o presidente aqui falar sem ter conhecimento prévio do seu auditório. Já visando ao sucesso, a sua oratória foi construída de acordo com aquilo que ele supunha que seria agradável ao seu público. Dessa forma, há um entrecruzamento de imagens que levam à construção do discurso.

Passamos agora a analisar a imagem que se revela por meio da palavra, o ethos discursivo, ressaltando aqui que seguimos a versão 
traduzida do discurso, disponível no portal G1, após confrontá-la com a versão original disponível no site da Casa Branca ${ }^{4}$.

Para Charaudeau (2008, p.118) o orador do discurso político "precisa ser crível e suporte da identificação à sua pessoa. Crível, porque não há político sem que se possa crer em seu poder de fazer; suporte de identificação, porque para aderir às suas ideias é preciso aderir a sua pessoa." Daí resultariam, segundo Charaudeau (2008), as duas figuras identitárias do discurso político, que vêm a ser duas grandes categorias de ethos: o ethos de credibilidade e o ethos de identificação.

\section{1- A CONSTRUÇÃO DA CREDIBILIDADE}

Em relação a essa primeira categoria, os ethé de credibilidade, Charaudeau (2008, p.119-137) faz referência a uma qualidade resultante da construção de uma identidade discursiva pelo sujeito que Ihe permita ser visto como possuidor do ethos de sério, de virtuoso e de competente.

Quanto ao ethos "de sério", este seria construído, ainda segundo Charaudeau (2008, p.120), por meio índices. Índices corporais e mímicos, dos quais não trataremos em razão de nos estarmos atendo à parte verbal do discurso, ainda que ele possa ser confirmado na versão "on-line", disponível para acesso. Índices comportamentais, que denotam autocontrole emocional em relação às críticas, não se deixando tomar por acessos de cólera; sangue-frio diante da adversidade; "índices que demonstram grande capacidade de trabalho, onipresença em todas as linhas de frente da vida política e social, particularmente diante daqueles que sofrem.", de acordo com Charaudeau (ibidem). Quanto a sua vida privada, esta não deve

\footnotetext{
${ }^{4}$ Observou-se que o trecho "that the future of the Arab World will be" foi traduzido por "o futuro do nosso mundo era" em lugar de "o futuro do Mundo Árabe será."
} 
permitir suspeita de infidelidade ou de indiferença quanto a sua família.

O ethos "de virtude", fundamental à imagem política, de um representante do povo, exige do político a construção de uma imagem que demonstre ser ele possuidor de características como sinceridade, fidelidade e honestidade pessoal. Essa imagem será construída ao longo de sua vida pública e será ela que dará suporte ao seu discurso, tornando-o crível ou não.

Quanto ao ethos "de competência", Charaudeau (2008, p.125) reconhece a necessidade de saber e habilidade por parte do político. Segundo o teórico, "os políticos devem, portanto, mostrar que conhecem todas as engrenagens da vida política e que sabem agir de maneira eficaz." Assim, ao fazer uso da palavra, o político poderá dar a perceber a sua competência ao falar sobre seus feitos, as funções exercidas, a experiência adquirida ao longo de sua carreira política.

No discurso de Barack Obama, o ethos de "sério" começa a ser construído logo no início da sua fala, nos trechos em que cita a sua família, mulher e filhas, que o acompanha na viagem e também quando se refere novamente à família, mas agora na figura de sua mãe, quando, para demonstrar a sua primeira ligação com o Brasil, cita o filme brasileiro Orfeu negro, dizendo "um filme que vi com minha mãe" e ainda afirma que sua mãe jamais o imaginaria visitando o Brasil como presidente da República. Há ainda presente a preocupação demonstrada pelo presidente em relação à crise financeira mundial, com a intenção de "restaurar o crescimento e a confiança [...] para manter nossas economias crescendo". Quanto à preocupação com aqueles que sofrem, Barack Obama diz sobre o Brasil e os Estados Unidos "estamos trabalhando lado a lado para combater a fome, doença e corrupção que podem apodrecer uma sociedade e roubar seus seres humanos". É ainda citada a sua (nossa) preocupação com o meio ambiente e com o futuro do planeta ao falar sobre "a criação de fontes de energia limpas e renováveis" e 
ainda quanto a "deixar para os nossos filhos um mundo mais limpo e mais seguro do que encontramos". Todas essas declarações a que nos referimos podem exemplificar a seriedade do orador.

Quanto ao ethos "de virtude", consideramos que já havia sido previamente construído de maneira positiva, uma vez que os aspectos sinceridade, fidelidade e honestidade pessoal não têm sido questionados na mídia, nem a sua conduta tem deixado margem a questionamentos. Assim, acreditamos que o auditório tenha recebido a sua fala com base nesses aspectos de sua personalidade.

Quanto ao ethos "de competência", a sua demonstração não nos parece ter sido um objetivo do orador, uma vez que não faz referência ao seu passado ou ao seu período na presidência. Isso talvez se deva ao fato de, como foi explicitado pelo orador, estar o Discurso da Cinelândia voltado para o povo brasileiro. O presidente não teria vindo falar do quanto os Estados Unidos podem fazer pelo Brasil, mas o quanto o Brasil é importante para os Estados Unidos neste momento.

\section{2- A CONSTRUÇÃO DA IDENTIFICAÇÃO}

Trataremos agora da segunda das duas figuras identitárias de que nos fala Charaudeau em relação ao discurso político: os ethé de identificação. Se os ethé de credibilidade visam dar confiabilidade à palavra do orador, os de identificação ligam-se ao aspecto afetivo da relação orador/auditório. São manifestações de caráter emocional, portanto, pessoais, que se destinam a promover a adesão do auditório. Para Charaudeau (2008, p.137), as imagens dos ethé de identificação "são extraídas do afeto social: o cidadão, mediante um processo de identificação irracional, funda sua identidade na do político." Ainda que essas imagens sejam, segundo o teórico, "destinadas a tocar o maior número de indivíduos [...] esse maior número é heterogêneo e vago do ponto de vista dos imaginários." 
(ibidem). Dessa forma, o estabelecimento ou a construção dos ethé de identificação sempre será dependente daquilo que se supõem ou se tem como verdade acerca do auditório. Para quem vou falar; quais as características do meu auditório; sobre quais "imaginários sociais" devo alicerçar as minhas palavras? Essas são questões que o orador se faz ao produzir o seu discurso e não se pode deixar de perceber o quanto o pathos, ou a mobilização do emocional, será aqui relevante.

Charaudeau (2008, p.137-166) relaciona como imagens que caracterizam o ethos de identificação: i) o ethos de "potência", ii) o ethos de "caráter" sobre o qual cita as seguintes figuras: a vituperação, cujas variantes são a provocação e a polêmica; a força tranquila, correlacionada ao controle de si; a coragem; o orgulho; a firmeza e a moderação, iii) o ethos de "inteligência", que se identifica por meio de duas figuras: a do homem culto que algumas culturas acreditam só poder ser um homem de bem e a da astúcia ou malícia, iv) o ethos de "humanidade", por meio da figuras do sentimento, da confissão, da intimidade, v) o ethos de "chefe", por meio das figuras de guia, de soberano e de comandante vi) o ethos de "solidariedade", atitude que se caracteriza por um movimento assimétrico entre um indivíduo que sofre e outro que, apesar de não sofrer, está, no entanto, emocionado pelo sofrimento alheio.

No "Discurso da Cinelândia", é bastante clara a opção pela construção do ethos de identificação. Isso pode ser percebido por meio das figuras presentes na fala do presidente norte- americano, ainda que nem todas comprovem com exatidão as diversas possibilidades anteriormente discriminadas. É o que se percebe quanto ao ethos de "potência" que, segundo Charaudeau (2008, p.139), pode se manifestar por meio da figura da virilidade sexual ou ainda do uso da violência verbal em relação aos adversários políticos. Não são essas marcas presentes no discurso aqui analisado. Nota-se, porém, uma forte construção de um ethos de autoridade importante, ou de superioridade, na frase "Eu sei que os brasileiros não abrem 
mão do seu futebol tão facilmente" em relação ao período anterior "Quero agradecer a todos por estarem aqui, pois me disseram que há um jogo do Vasco ou do Botafogo", pois implica a ideia de que os brasileiros preferiram ouvir o presidente Barack Obama a assistir ao futebol.

Relativas ao ethos de "caráter", podem ser reconhecidas as figuras força tranquila e controle de si, pois, ainda que não manifeste verbalmente, o presidente americano conduz a sua fala de forma assertiva ao se referir ao que já foi pensado pelo seu governo quanto à necessidade de ampliar a parceria entre o Brasil e os Estados Unidos. Sem imposições, em tom de conselho, ele diz, no sexto $\left(6^{\circ}\right)$ parágrafo "Vim aqui para compartilhar algumas ideias, pois quero falar sobre os valores que compartilhamos, as esperanças que temos em comum e a diferença que podemos fazer juntos.". Além disso, reforçando aquilo que já pode ser considerado como uma marca pessoal, o controle de si foi sempre uma constante, pois em nenhum momento houve um descontrole, palavras mais carregadas de emoção, ainda que em seu conteúdo o discurso fizesse apelo ao emocional, o pathos, do povo brasileiro.

Presente ao longo de toda a fala está o ethos de "inteligência", por meio da figura do homem culto que se manifesta como um profundo conhecedor não só da história do Brasil, mas também da cultura e da política brasileira, como nos trechos que seguem, respectivamente sétimo $\left(7^{\circ}\right)$, nono $\left(9^{\circ}\right)$, décimo $\left(10^{\circ}\right)$ e quarto $\left(4^{\circ}\right)$ parágrafos:

São duas terras com abundantes recursos
naturais, terras natais de povos indígenas
antiqüíssimos.[... Nos tornamos colônias
dominadas por coroas distantes, mas logo
declaramos nossa independência e em seguida
recebemos grandes quantidades de imigrantes em
nossas costas e mais tarde, depois de muita luta,
limpamos a mancha da escravidão de nossas
terras.


No Brasil vocês lutaram contra duas décadas de ditadura, lutando pelo mesmo direito de ser ouvidos, o direito de ser livres, livres do medo, livres da necessidade.

Hoje o Brasil é uma democracia desabrochando, um lugar onde as pessoas são livres para falar o que pensam e escolher seus líderes e onde um garoto pobre de Pernambuco pode sair de uma fábrica de cobre e chegar ao gabinete mais elevado no país.

Vocês são, como cantor Jorge Benjor diz, "um país tropical abençoado por Deus e bonito por natureza.

A referência ao escritor Paulo Coelho "acreditamos nas palavras de Paulo Coelho, um de seus mais famosos escritores" no trigésimosegundo (320) parágrafo, ao encerrar o discurso, além de confirmar a recorrente intenção do orador de apelar para imagens facilmente identificáveis por grande parte do povo brasileiro, deixa também entrever uma realidade irrefutável, que é a da imensa popularidade que o citado escritor consolidou mundo afora.

O ethos de "solidariedade", diz Charaudeau (2008, p.138), "faz do político um ser que não somente está atento às necessidades dos outros, mas que as partilha e se torna responsável por elas." Em seu discurso, ainda que não seja uma constante, o presidente lembra atos de solidariedade praticados pelos governos brasileiro e norteamericano, no seguinte trecho do vigésimo $\left(20^{\circ}\right)$ parágrafo:

Da África ao Haiti, estamos trabalhando lado a lado para combater a fome, doença e corrupção que podem apodrecer uma sociedade e roubar seres humanos de sua dignidade e oportunidades.

Não nos parece ter havido a intenção no discurso de Barack Obama de deixar predominar o ethos de "chefe", que the conferiria uma marca de superioridade, dele como presidente, e dos Estados Unidos, país considerado como superpotência, bem distante do Brasil, 
considerado um país emergente. Há, ao longo da fala do presidente americano, o uso recorrente do pronome "nós" em referência aos dois países, marcando identidades históricas, políticas e de desenvolvimento futuro, como nos trechos a seguir, respectivamente, décimo-sexto $\left(16^{\circ}\right)$ e vigésimo-terceiro $\left(23^{\circ}\right)$ parágrafos:

Juntos, podemos aumentar nossa prosperidade em comum.

Ambos acreditamos no poder e na promessa da democracia, acreditamos que nenhuma forma de governo é mais eficaz na promoção do crescimento e prosperidade que alcança todo ser humano, não apenas alguns, mas todos.

Assim, o que sobressai são as marcas de igualdade ou de semelhança entre os dois países.

Mas é possível identificar, ainda que de forma bastante restrita, a fala que se manifesta do lugar de chefe, daquele que está em posição acima do outro, o auditório, o povo brasileiro, como neste trecho do décimo-quinto $\left(15^{\circ}\right)$ parágrafo, em que o uso dos qualificadores "sênior" e "júnior" e do advérbio "como" revela o reconhecimento da distância que ainda separa os dois países.

... o povo americano não apenas reconhece o sucesso do Brasil, nós torcemos pelo sucesso do Brasil enquanto vocês confrontam os muitos desafios que ainda enfrentam no Brasil e no exterior, vamos ficar juntos, não são como parceiros sênior e júnior, mas como parceiros iguais, unidos pelo espírito do interesse comum e do respeito mútuo...

Quanto ao ethos de "humanidade", ele pode ser identificado por meio das figuras da confissão, presente em "Vocês sabem que esta cidade não foi a minha primeira escolha para os jogos olímpicos..."; do sentimento, quando o presidente se refere às causas ambientais em "..deixar para os nossos filhos um mundo mais limpo e mais 
seguro do que encontramos" ou "Os japoneses são alguns de nossos amigos mais próximos e ficaremos ao lado deles, rezaremos com eles e reconstruiremos com eles..."

É ainda Charaudeau (2008, p.184) quem afirma que "Há um tempo para os ethé de credibilidade e outro para os de identificação." Por meio da análise aqui feita, foi possível perceber que, no Discurso da Cinelândia, um maior tempo foi dedicado aos ethé de identificação, já que houve um predomínio de manifestações voltadas para o aspecto afetivo da relação entre o Brasil e os Estados Unidos, na figura do seu presidente, o orador. Por meio de repetidos elogios ao povo brasileiro, aos seus feitos, a sua coragem, ao seu crescimento econômico, a sua luta contra a ditadura e mesmo atualmente contra a violência, em especial na mesma cidade do Rio de Janeiro onde o discurso foi proferido, o auditório foi mobilizado predominantemente pela emoção. Para Charaudeau (2008, p.180) o ethos assim construído "teria uma função ofuscante que oculta o logos, a razão, por seu jeito de evidência que não se discute", o que nos leva a pensar que a identidade intuída entre o ufanismo da famosa "Aquarela do Brasil", de autoria de Ari Barroso, e o discurso de Barack Obama nada mais foi do que uma estratégia para nos fazer tomar conhecimento de "algumas ideias" que o governo americano tem em relação ao Brasil neste momento.

\section{CONCLUSÃO}

No prólogo do seu livro Discurso Político, Charaudeau (2008, p.8) afirma que "toda palavra pronunciada no campo político deve ser tomada ao mesmo tempo pelo que ela diz e não diz". O discurso que Barack Obama proferiu no Theatro Municipal do Rio de Janeiro é um exemplo dessa afirmação. Coube ao presidente dos Estados Unidos escolher a máscara, tendo em vista a plateia presente e o interesse de sua visita ao Brasil. Esse jogo de máscaras, como bem diz 
Charaudeau, tem o intuito de persuasão e de sedução, a partir de inúmeras estratégias que passam pela construção de um ethos, assim como do uso de imaginários sociodiscursivos aceitos, em geral, pela sociedade ocidental. Desse modo, a análise do "Discurso da Cinelândia" nos permite dizer que a mobilização do auditório em seu favor se deu por meio das inúmeras referências aos imaginários sociodiscursivos, com base em estereótipos, por meio dos quais o povo brasileiro é identificado, mas também por meio de estereótipos que identificam a sociedade norte-americana, como a liberdade, a igualdade, a tecnologia e, por fim, a democracia. A nossa proposta foi mostrar que o "Discurso da Cinelândia", um discurso político, é um jogo de linguagem em que todo o dizer tem um objetivo e, consequentemente, constitui um efeito de sentido.

\section{REFERÊNCIAS:}

AMOSSY, Ruth (org.). Imagens de si no discurso: a construção do ethos. São Paulo: Editora Contexto, 2005.

CHARAUDEAU, Patrick. Discurso Político. São Paulo: Editora Contexto, 2008. 


\section{ANEXO}

Discurso de Barack Obama ${ }^{5}$

Alô, Rio de Janeiro.

Alô, Cidade Maravilhosa.

Boa tarde, todo o povo brasileiro.

Desde o momento em que chegamos o povo desta nação tem gentilmente mostrado à minha família o calor e a generosidade do espírito brasileiro, obrigado. Quero agradecer a todos por estarem aqui, pois me disseram que há um jogo do Vasco ou do Botafogo... Eu sei que os brasileiros não abrem mão de seu futebol tão facilmente.

Uma das primeiras impressões que tive do Brasil veio de um filme que vi com minha mãe quando eu era muito pequeno. Um filme chamado "Orfeu negro", que se passava nas favelas durante o carnaval. E minha adorava aquele filme, tinha música e dança e como pano de fundo, os lindos morros verdes. Esse filme estreou primeiramente como uma peça bem aqui, no Theatro Municipal.

Minha mãe já faleceu, mas ela jamais imaginaria que a primeira viagem de seu filho ao Brasil seria como presidente dos EUA. Ela jamais imaginaria isso. E eu jamais imaginaria que este país seria ainda mais bonito do que no filme. Vocês são, como cantor Jorge Benjor diz, "um país tropical abençoado por Deus e bonito por natureza".

Vi essa beleza nas encostas dos morros, nas infindáveis milhas de areia e oceano e nas vibrantes e diversificadas multidões de brasileiros que vieram aqui hoje. $E$ nós temos um grupo maravilhosamente misturado: cariocas, paulistas, baianos, mineiros. Temos homens e mulheres das cidades até o interior e tanta gente jovem aqui, que são o grande futuro desta grande nação.

${ }^{5}$ Disponível em: <www.g1.globo.com/obama-no-brasil/noticia/2011/03/leia-integra-dodiscurso-de-barack-obama-no-theatro-municipal.html.> Acesso em: 25 de outubro de 2011. Não houve interferências das autoras do artigo em relação ao que se denomina "erros" de língua portuguesa. 
Ontem tive um encontro com sua maravilhosa nova presidente, Dilma Rousseff, e conversamos sobre como fortalecer a parceria entre nossos governos. Mas hoje quero falar diretamente com o povo brasileiro sobre como podemos fortalecer a amizade entre nossos países. Vim aqui para compartilhar algumas ideias, pois quero falar sobre os valores que compartilhamos, as esperanças que temos em comum e a diferença que podemos fazer juntos.

Se você parar para pensar, as jornadas dos EUA e do Brasil começaram de formas parecidas. São duas terras com abundantes recursos naturais, terras natais de povos indígenas antiquíssimos. As Américas foram descobertas por homens que vieram do outro lado do oceano como um "novo mundo" e colonizadas pelos pioneiros que ampliaram os territórios rumo ao Oeste atravessando imensas fronteiras. Nos tornamos colônias dominadas por coroas distantes, mas logo declaramos nossa independência e em seguida recebemos grandes quantidades de imigrantes em nossas costas e mais tarde, depois de muita luta, limpamos a mancha da escravidão de nossas terras.

Os EUA foram a $1^{a}$ nação a reconhecer a independência do Brasil e a $1^{\text {a }}$ a estabelecer um posto diplomático neste país. O primeiro líder de um país a visitar os EUA foi Dom Pedro II. Na Segunda Guerra Mundial nossos corajosos homens e mulheres lutaram lado a lado pela liberdade. E depois da guerra, nossas duas nações lutaram para conseguir as bênçãos plenas da liberdade.

Nas ruas dos EUA, homens e mulheres marcharam e sangraram e alguns até morreram para que todos os cidadãos pudessem usufruir das mesmas liberdades e oportunidades, não importa como fosse sua aparência, não importa de onde você viesse. No Brasil vocês lutaram contra duas décadas de ditadura, lutando pelo mesmo direito de ser ouvidos, o direito de ser livres, livres do medo, livres da necessidade. E mesmo assim, durante anos, a democracia e o desenvolvimento 
demoraram a se estabelecer e milhões sofreram por causa disso.

Mas venho aqui hoje porque esses dias passaram. Hoje o Brasil é uma democracia desabrochando, um lugar onde as pessoas são livres para falar 0 que pensam e escolher seus líderes e onde um garoto pobre de Pernambuco pode sair de uma fábrica de cobre e chegar ao gabinete mais elevado no país. Na última década, o progresso feito pelo povo brasileiro inspirou o mundo.

Pois hoje metade deste país é considerado classe média. Milhões foram retirados da pobreza. Pela primeira vez a esperança está voltando a lugares onde antes prevalecia o medo. Eu vi isso hoje, quando visitei a Cidade de Deus. Não se trata apenas dos novos esforços com segurança e programas sociais. E quero dar os parabéns ao prefeito e ao governador pelo excelente trabalho que estão fazendo. Mas também é uma mudança de atitude.

Como um jovem morador disse, as pessoas não devem olhar a favela com pena, mas como uma fonte de presidentes, advogados, médicos, artistas e pessoas com soluções. A cada dia que passa, o Brasil é um país com mais soluções. $\mathrm{Na}$ comunidade global vocês passaram de contar com - ajuda de outros países a agora ajudar a lutar contra a pobreza e a doença onde quer que elas existam.

Vocês desempenham um papel importante nas instituições globais ao promover nossa segurança como um todo e nossa prosperidade como um todo. E vocês receberão o mundo em seu país quando a Copa do Mundo e os Jogos Olímpicos vierem ao Rio de Janeiro. Vocês sabem que esta cidade não foi minha primeira escolha para os jogos olímpicos, mas, se os jogos não pudessem ser realizados em Chicago, não tem lugar em que eu gostaria mais de vê-los do que aqui no Rio.

Por isso pretendo voltar em 2016 para ver o que acontece. O Brasil foi durante muito tempo um país cheio de potencial, mas atrasado pela política, 
tanto aqui quanto no exterior. Durante muito tempo o Brasil foi o "país do futuro" e disseram para que ele esperasse pelos dias melhores que viriam em breve. Meus amigos, este dia finalmente chegou. Este não é mais o "país do futuro", as pessoas do Brasil devem saber que o futuro já chegou e está aqui agora. É hora de tomar posse dele.

Nossos países nem sempre concordaram em tudo. E assim como ocorre com muitas nações, teremos nossas diferenças de opinião ao avançar. Mas estou aqui para lhes dizer que o povo americano não apenas reconhece o sucesso do Brasil, nós torcemos pelo sucesso do Brasil enquanto vocês confrontam os muitos desafios que ainda enfrentam em casa e no exterior, vamos ficar juntos, não são como parceiros sênior e júnior, mas como parceiros iguais, unidos pelo espírito do interesse comum e do respeito mútuo, comprometidos para com o progresso que sei que podermos fazer juntos.

Tenho certeza de que podemos fazer isso. Juntos, podemos aumentar nossa prosperidade em comum. Sendo duas das maiores economias do mundo, trabalhamos lado a lado durante a crise financeira para restaurar o crescimento e confiança. E para manter nossas economias crescendo, sabemos do que é necessário em ambas as nações. Precisamos de uma força de trabalho capacitada e é por isso que empresas brasileiras e americanas assumiram um compromisso de aumentar o intercâmbio de estudantes entre nossas nações.

Precisamos de um compromisso com a inovação e a tecnologia, por isso concordamos em aumentar a cooperação entre nossos cientistas, pesquisadores e engenheiros. Precisamos de infra estrutura da mais alta qualidade e por isso as empresas americanas também querem ajudá-los a construir e preparar a cidade para o sucesso olímpico. Numa economia globalizada, os EUA e o Brasil deveriam expandir o comércio, expandir investimentos, de modo a criar novos empregos e novas oportunidades em ambas nossas nações por isso 
estamos trabalhando para derrubar barreiras para fazer negócios.

Por isso estamos criando relacionamentos mais próximos entre nossos trabalhadores e nossos empreendedores. Juntos também podemos trabalhar pela segurança da energia e proteger nosso lindo planeta.

Sendo dois países comprometidos com economias mais verdes, sabemos que a solução definitiva ao desafio da energia virá da criação de fontes de energias limpas e renováveis. Por isso a metade dos carros daqui pode circular com biocombustível e a maior parte de sua eletricidade vem de hidroelétricas. $E$ por isso também demos início a uma nova indústria limpa de energia nos EUA. Por isso os EUA e o Brasil estão criando novas parcerias na área de energia, para compartilhar, criar novos empregos e deixar para nossos filhos um mundo mais limpo e mais seguro do que encontramos.

Juntas, nossas duas nações também podem ajudar a defender a segurança de nossos cidadãos. Estamos trabalhando juntos para deter 0 narcotráfico que destruiu vidas demais neste hemisfério. Buscamos o objetivo de um mundo sem armas nucleares. Estamos trabalhando juntos para aumentar nossa segurança ente hemisférios. Da África ao Haiti, estamos trabalhando lado a lado para combater a fome, doença e corrupção que podem apodrecer uma sociedade e roubar seres humanos de sua dignidade e oportunidades.

Sendo dois países que foram tão enriquecidos pela herança africana, é vital que trabalhemos juntos com o continente africano para ajudá-lo a se erguer. É algo que devemos nos comprometer a fazer, juntos. Hoje também estamos dando apoio e ajuda ao povo japonês em sua maior hora de necessidade. Os laços que unem nossa nação ao Japão são fortes. O Brasil é o lar da maior população japonesa fora do Japão. Nos EUA, solidificamos uma aliança com eles que já tem mais de 60 anos. 
Os japoneses são alguns de nossos amigos mais próximos e ficaremos ao lado deles, rezaremos com eles e reconstruiremos com eles até que essa crise esteja terminada. Nestes e em outros esforços para promover paz e prosperidade no mundo todo, os EUA e o Brasil são parceiros não apenas porque compartilhamos história ou por estarmos no mesmo hemisfério, não apenas por compartilharmos laços de comércio e cultura, mas também porque compartilhamos de valores e ideais duradouros.

Ambos acreditamos no poder e na promessa da democracia, acreditamos que nenhuma forma de governo é mais eficaz na promoção de crescimento e prosperidade que alcança todo ser humano, não apenas alguns, mas todos. $E$ aqueles que discordam dizendo que a democracia atrapalha o crescimento econômico devem argumentar com o exemplo do Brasil. Com os milhões que subiram da pobreza para a classe média não o fizeram numa economia fechada controlada pelo estado, mas o fizeram como um povo livre, com mercados livres e um governo que responde a seus cidadãos.

Vocês são a prova de que justiça social e inclusão social podem ser melhor conquistadas por meio da liberdade e que a democracia é a maior parceira do progresso humano. Também acreditamos que em países tão grandes e diversos quanto os nossos, moldados por gerações de imigrantes de todas as raças, fés e culturas, a democracia dá a maior esperança de que todos os cidadãos sejam tratados com dignidade e respeito. E que podemos resolver nossas diferenças pacificamente $e$ encontrar força em nossa diversidade.

Nós sabemos nos EUA como é importante poder trabalhar juntos, mesmo quando discordamos. Entendo que a forma de governo que escolhemos pode ser lenta e confusa. Entendemos que a democracia precisa ser fortalecida e aperfeiçoada com o tempo. Sabemos que diferentes países escolhem caminhos diferentes para atingir a promessa da democracia. $E$ entendemos que nenhum país deve impor sua vontade sobre outro. 
Mas também sabemos que existem certas aspirações compartilhadas por todo ser humano. Todos queremos ser livres, queremos ser ouvidos, todos ansiamos por viver sem medo ou discriminação. Todos queremos escolher como seremos governados. Todos querem moldar seu próprio destino. Esses não são ideais americanos ou ideais brasileiros, não são ideais ocidentais, são direitos universais. E devemos apoiá-los em toda parte. Hoje estamos vendo a luta por esses direitos acontecendo no Oriente Médio e no Norte da África.

Vimos uma revolução nascer de um anseio por dignidade humana básica na Tunísia e vimos manifestantes pacíficos, homens e mulheres, jovens e velhos, cristão e muçulmanos, ocupando praça Tahir e vimos o povo da Líbia se defendendo corajosamente contra um regime determinado a tratar com brutalidade seus próprios cidadãos. Em toda parte vimos jovens se erguendo. Uma nova geração exigindo o direito de determinar seu próprio futuro.

Desde o início deixamos claro que a mudança que buscam devem ser impulsionadas pelo seu próprio povo. Mas para nossos dois países, para os EUA e para o Brasil - duas nações que passaram muitas gerações lutando para aperfeiçoar suas próprias democracias - os EUA e o Brasil sabem que o futuro de nosso mundo era determinado pelo seu povo. Ninguém pode dizer ao certo como essa mudança terminará. Mas eu sei que mudança não é algo que devemos temer.

Quando os jovens insistem que as correntes da História estão se movendo, a carga do passado pode ser apagada. Quando homens e mulheres exigem pacificamente seus direitos humanos nossa humanidade em comum é acentuada. Onde quer que a luz da liberdade seja acesa, o mundo se torna um mais luminoso.

Esse é o exemplo do Brasil. Esse é o exemplo do Brasil. Brasil, um país que prova que uma ditadura pode se tornar uma próspera democracia. Brasil, um país que mostra que a democracia entrega 
liberdade e oportunidade a seu povo. Brasil, um país que mostra que um grito por mudanças vindo das ruas pode mudar uma cidade, mudar um país, mudar o mundo. Há décadas, foi aqui fora, na praça da Cinelândia, o grito por mudança foi ouvido aqui, estudantes e artistas e políticos de todas as correntes ergueram faixas que diziam "abaixo a ditadura", as pessoas no poder.

Suas aspirações democráticas não seriam realizadas ainda por muito tempo. Mas um dos jovens brasileiros envolvidos naquele movimento iria mudar para sempre a história deste país. A filha de um imigrante. Sua participação no movimento fez com que fosse presa e torturada por seu próprio governo. Ela sabe o que é viver sem seus direitos mais básicos pelos quais tantos lutam hoje. Mas ela também sabe o que é perseverar. Ela sabe o que é triunfar. Porque hoje é ela é a presidente de seu país, Dilma Rousseff.

Nossos dois países enfrentam muitos desafios. Na estrada à nossa frente, com certeza encontraremos muitos obstáculos. Mas no fim, é nossa história que nos dá esperança para um amanhã melhor. É o conhecimento de que os homens e mulheres que vieram antes de nós superaram desafios maiores que estes e que vivemos em lugares em que pessoas comuns fizeram coisas extraordinárias.

Esse senso de possibilidade e de otimismo que primeiro atraiu pioneiros a este mundo. $E$ isso une nossas nações como parceiros nesse novo século, por isso acreditamos nas palavras de Paulo Coelho, um de seus mais famosos escritores, que "com a força de nosso amor e nossa vontade podemos mudar nosso destino. $E$ também $O$ destino de muitos outros".

Muito obrigado. E que Deus abençoe nossas duas nações. 